\title{
An Accounting Information Systems Perspective On Data Analytics And Big Data During 2015-2020
}

\author{
${ }^{1}$ Jesús Vargas Villa, ${ }^{2}$ Mohammad Haroun Sharairi, ${ }^{3}$ Alberto Clavería Navarrete ${ }^{[0000-0002-4957-7738]}$, \\ ${ }^{4}$ Gerber F.Incacari Sancho ${ }^{[0000-0003-1590-6035]}$ \\ ${ }^{1}$ Universidad de la Costa, Barranquilla, Colombia \\ ${ }^{2}$ Assistant Professor, College of Business, Al Ain University, UAE. \\ ${ }^{3}$ Universidad de Sevilla, España \\ ${ }^{4}$ Universidad Nacional del Callao, Lima, Perú \\ 1*jvargas41@ cuc.edu.co, ${ }^{2}$ mohammad.sharairi@aau.ac.ae, ${ }^{3}$ claveria.alberto@gmail.com, \\ ${ }^{4}$ gfincacaris@unac.edu.pe
}

Article History: Received: 11 January 2021; Accepted: 27 February 2021; Published online: 5 April 2021

\begin{abstract}
Accounting information systems are responsible for providing information that constitutes raw material for decision making in terms of investment, payments to suppliers, payroll, income, among others. The analysis of such information becomes a cornerstone in the positioning strategies through productivity and competitiveness of any organization. When this analysis is applied to large volumes of information, there are Big Data tools that facilitate the grouping of data according to its source or nature. This paper will describe the most influential accounting information systems in the analysis of large volumes of data that affect the decision making of companies in different sectors of the economy during the period between 2015 and 2020.
\end{abstract}

Keywords: Accounting information system, Data analytics, Big Data.

\section{Introduction}

In the development of economic activity in any organization, essential information is produced for the analysis and operation of the same. In accounting, the movements of assets and liabilities constitute a series of strategies for the correct use of resources. It is important to emphasize that both accounting and accounting systems are the result of a historical journey and overcoming in the application of tools and instruments of management to assist in the management of resources in the organization(Barrios, 2017).

In the development of economic activity in any organization, essential information is produced for the analysis and operation of the same. In accounting, the movements of assets and liabilities constitute a series of strategies for the correct use of resources. It is important to emphasize that both accounting and accounting systems are the result of a historical journey and overcoming in the application of tools and instruments of management to assist in the management of resources in the organization.

Currently, companies face the challenge of analyzing large volumes of information by applying Big Data techniques to achieve a real approach to a thorough study of market needs. This research will determine the importance of the analysis of data derived from accounting information systems by reviewing the studies conducted on these topics during the period 2015-2020, which will be an important input for decision making in any organization.

\section{General Objective}

To analyze the impact of accounting information systems and Big Data techniques through a review of scientific articles published in journals indexed in Scopus database in the period 2015-2020.

\section{Accounting information systems.}

Understanding the accounting information systems determines the accuracy and efficiency of the information derived from the analysis of the data provided by the application of tools that management uses to measure the performance of its resources through the implementation of organizational strategies in search of profitability and positioning of each company. The analysis of such information is processed through techniques established not only by the organization but also by a whole conglomerate of experiences shared at different moments in history, i.e., such systems are fed by the results of each economic activity in the immediately preceding period.

Thanks to research and the effort to achieve a larger and larger market share, companies are experimenting with different strategies for this purpose, which has led to the development of more and more new tools for the organization of large amounts of information such as the techniques proposed in Big Data, which organizes such data in such a way that information systems will be more efficient in their analysis.

Information systems are an integrated and coordinated set of people and material resources and procedures that capture and process data to transform it into information, which is stored in databases for efficient decision making (Barrios, 2017). 


\subsection{Review of the scientific production of the variable Accounting Information Systems.}

After analyzing the information provided by the Scopus database, there is evidence of a low production of scientific papers published in high impact journals that handle the variable Accounting Information Systems in the period 2015-2020 where a total of 3 research papers are listed in Table 1.

Table 1. Papers related to the variable Accounting Information Systems

\begin{tabular}{|l|c|c|c|c|}
\hline \multicolumn{1}{|c|}{ Title } & Author(s) & $\begin{array}{c}\text { Year of } \\
\text { Publication }\end{array}$ & $\begin{array}{l}\text { Country of } \\
\text { Publication }\end{array}$ & Citations \\
\hline $\begin{array}{l}\text { Electronic accounting } \\
\text { information systems in the } \\
\text { provision of cash budgeting } \\
\text { and supply chain management }\end{array}$ & Koshan, H.M. & 2019 & Iraq & 0 \\
\hline $\begin{array}{l}\text { Influence of the Accounting } \\
\text { Information Systems and } \\
\text { internal auditory in fraud } \\
\text { financial reports }\end{array}$ & $\begin{array}{c}\text { Mulyani, S., Kasim, E., } \\
\text { Yadiati, W., Umar, H. }\end{array}$ & 2019 & Indonesia & 3 \\
\hline $\begin{array}{l}\text { Effect of the Risk } \\
\text { Management in the quality of } \\
\text { the Accounting information } \\
\text { systems: } \\
\text { Adaptability, and usability of } \\
\text { the dimensions }\end{array}$ & $\begin{array}{c}\text { Meiryani, M., Siagian, P., } \\
\text { Yadiati, W., Warganegara, }\end{array}$ & 2018 & Indonesia & 0 \\
\hline
\end{tabular}

Source: Own elaboration 2021, based on data provided by SCOPUS.

It is worth noting that, in the papers registered in the previous chart, the objective is the application of tools that are designed through the accounting information systems, with the purpose of optimizing the use of resources in the different areas of knowledge, which shows that the decision making of each organization is based precisely on the analysis of the information provided by the application of these management tools.

\section{Big Data in the organization.}

Data analysis through Big Data techniques significantly helps in the selection, organization and processing of information to ensure efficient decision making in any organization. For McKinsery Global Institute, "Big Data refers to data sets whose size is beyond the capabilities of typical database software tools to capture, store, manage and analyze".” (Aguilar, 2013).

Equally important to the organization is the origin or source of the data. It is known by theory that there are three main types of data that help to classify the information in a first instance (Structured, Semi-structured and Unstructured Data) and that are defined according to the format in which the data is captured. This is why it is vital for the company to clearly define an objective in the first instance in order to properly select the source from which the data necessary for subsequent analysis and application of measures will come from. The subsequent analysis of each group of data results in valuable information for decision making as it defines even sufficient input to forecast possible results after an investment, consumer responses to marketing strategies and even variation in prices of products and/or services in the market.

\subsection{Review of the scientific production of the Big Data variable in the organization.}

Currently, Big Data is a topic that has been widely studied and is the main subject of much research worldwide. The production of scientific articles involving this variable reaches high numbers, regardless of the area of knowledge where it is focused. However, for the present study the production of research papers 
published in journals indexed in the Scopus database on Big Data in the organization has been analyzed, yielding a total of 8 articles from 2015 to 2020 .

4.1.1 Distribution of papers by area of knowledge.

Figure 1. Distribution of papers by area of knowledge.

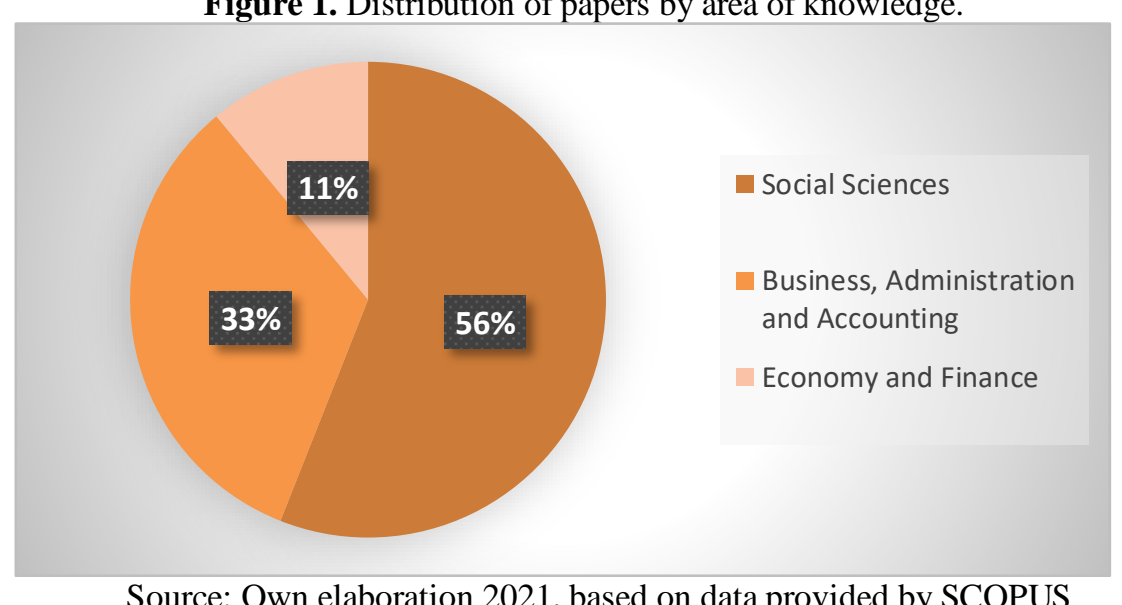

Taking into account that the study of the variable is limited only to those that have a direct relationship with the different areas of the organization, the general area resulting from this first analysis is, of course, administration, but within this area there are sub-areas that after analyzing this result it is worth highlighting.

Social sciences, whose main object of study is the administrative approach, have the highest representation of the production of scientific papers with the variable Big Data in the organization, sociological studies and human talent management are part of the related papers in this first part. Business, Administration and Accounting and Economics and Finance with 33\% and 11\% respectively, complete the totality of the studies carried out during the aforementioned period.

The organization is currently facing important challenges as the market becomes increasingly globalized and in an accelerated way, which leads to a vertiginous growth of each and every one of its internal areas, and this can only be achieved in the face of trends that frame consumer behavior. In the past, sales, for example, were seen as a transaction where the relationship with the customer ended once the final product was in the customer's hands and the customer paid the price established by the company. However, today customer relationships are becoming more and more lasting, at least that is the desire of the organization through CRM, loyalty, after-sales services, fulfillment of guarantees, among other strategies and all that information meets the characteristics of Big Data; its sources, speed, volume, etc.

\subsubsection{Distribution of articles by country of origin.}

Figure 2. Distribution of articles by country of origin.

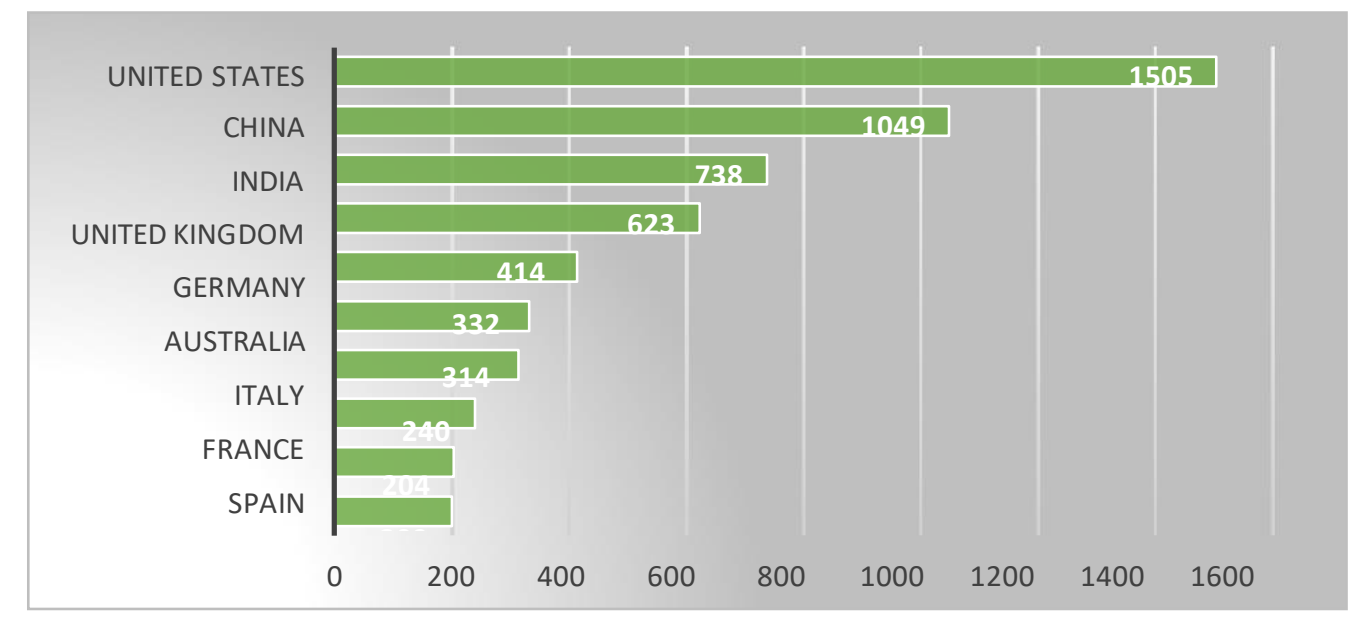

Source: Own elaboration 2021; from data supplied by SCOPUS. 
The Big data variable focused on studies concerning the different areas of the organization is analyzed, and it is observed that the country that produces the most scientific articles under said search parameter is the United States, which registers a total of 1,505 research papers published in journals. high impact indexed in Scopus database. Followed by two Asian powers such as China and India with 1,049 and 738 articles respectively, among which stands out "Big data analytics and firm performance: Effects of dynamic capabilities" (2017) whose main contribution is the verification of the contribution of the application of information systems with the effectiveness in the processes of a company using different study models proposed by the analysis of Big data focused on the organization. The delivery of the article related above can be measured by the number of citations it has had since its publication, a total of 452 that indicate that its results have served as input for the preparation or starting point for different research works.

The United Kingdom and Germany participate in the registry that shows the graph as the two European exponents with the highest publication of articles under the Big data variable focused on the organization, 623 and 414 jobs each reached between 2015 and 2020. It should be noted that the Figure 2 shows the top ten positions in terms of the ranking of countries with the most production where Indonesia closes with 200 articles published under the indicated variable, however, Table 2 shows the general count of the results of the search carried out in the database Scopus.

Table 2. Total distribution of articles by country of origin.

\begin{tabular}{|c|c|c|c|c|c|}
\hline COUNTRY & DOCUMENTS & COUNTRY & DOCUMENTS & COUNTRY & DOCUMENTS \\
\hline United States & 1505 & Ukraine & 27 & Zimbabwe & 3 \\
\hline China & 1049 & Hungary & 25 & Costa Rica & 2 \\
\hline India & 738 & Egypt & 22 & Jamaica & 2 \\
\hline United Kingdom & 623 & Slovenia & 22 & Kyrgyzstan & 2 \\
\hline Germany & 414 & Chile & 21 & Myanmar & 2 \\
\hline Australia & 332 & Jordan & 21 & Puerto Rico & 2 \\
\hline Italy & 314 & Israel & 20 & Yemen & 2 \\
\hline France & 240 & Oman & 20 & Armenia & 1 \\
\hline Spain & 204 & Colombia & 18 & Belarus & 1 \\
\hline Indonesia & 200 & Estonia & 17 & Bhutan & 1 \\
\hline Malaysia & 195 & Lebanon & 17 & Bosnia and Herzegovina & 1 \\
\hline South Korea & 185 & Cyprus & 16 & Chad & 1 \\
\hline Russian Federation & 177 & Bangladesh & 15 & Cote d'Ivoire & 1 \\
\hline Canada & 176 & Croatia & 15 & Grenada & 1 \\
\hline Netherlands & 163 & Philippines & 14 & Guatemala & 1 \\
\hline Hong Kong & 135 & Bulgaria & 12 & Libyan Arab Jamahiriya & 1 \\
\hline Brazil & 129 & Ghana & 12 & Monaco & 1 \\
\hline Portugal & 107 & Macao & 12 & Mongolia & 1 \\
\hline Taiwan & 106 & Qatar & 12 & Montenegro & 1 \\
\hline Norway & 104 & Serbia & 12 & Niger & 1 \\
\hline South Africa & 102 & Algeria & 10 & Papua New Guinea & 1 \\
\hline Japan & 100 & Argentina & 10 & Senegal & 1 \\
\hline Poland & 98 & Brunei Darussalam & 9 & Venezuela & 1 \\
\hline Finland & 97 & Iraq & 9 & Zambia & 1 \\
\hline Sweden & 97 & Liechtenstein & 9 & & \\
\hline Greece & 89 & Kenya & 8 & & \\
\hline Turkey & 86 & Luxembourg & 8 & & \\
\hline Switzerland & 80 & Ecuador & 7 & & \\
\hline Saudi Arabia & 78 & Kazakhstan & 7 & & \\
\hline Iran & 77 & Peru & 7 & & \\
\hline Pakistan & 73 & Sri Lanka & 7 & & \\
\hline Denmark & 70 & Kuwait & 6 & & \\
\hline United Arab Emirates & 69 & Bahrain & 5 & & \\
\hline New Zealand & 64 & Latvia & 5 & & \\
\hline Romania & 62 & Namibia & 5 & & \\
\hline Belgium & 61 & Albania & 4 & & \\
\hline Austria & 58 & Azerbaijan & 4 & & \\
\hline Czech Republic & 58 & Malawi & 4 & & \\
\hline Ireland & 56 & Mauritius & 4 & & \\
\hline Singapore & 56 & North Macedonia & 4 & & \\
\hline Morocco & 54 & Botswana & 3 & & \\
\hline Thailand & 52 & Cuba & 3 & & \\
\hline Viet Nam & 36 & Ethiopia & 3 & & \\
\hline Tunisia & 33 & Iceland & 3 & & \\
\hline Mexico & 32 & Malta & 3 & & \\
\hline Nigeria & 32 & Nepal & 3 & & \\
\hline Slovakia & 31 & Tanzania & 3 & & \\
\hline Lithuania & 29 & Uganda & 3 & & \\
\hline
\end{tabular}

Source: Own elaboration 2021; from data supplied by SCOPUS. 
4.1.3 Distribution of articles by type of publication.

Figure 3. Distribution of articles by type of publication.

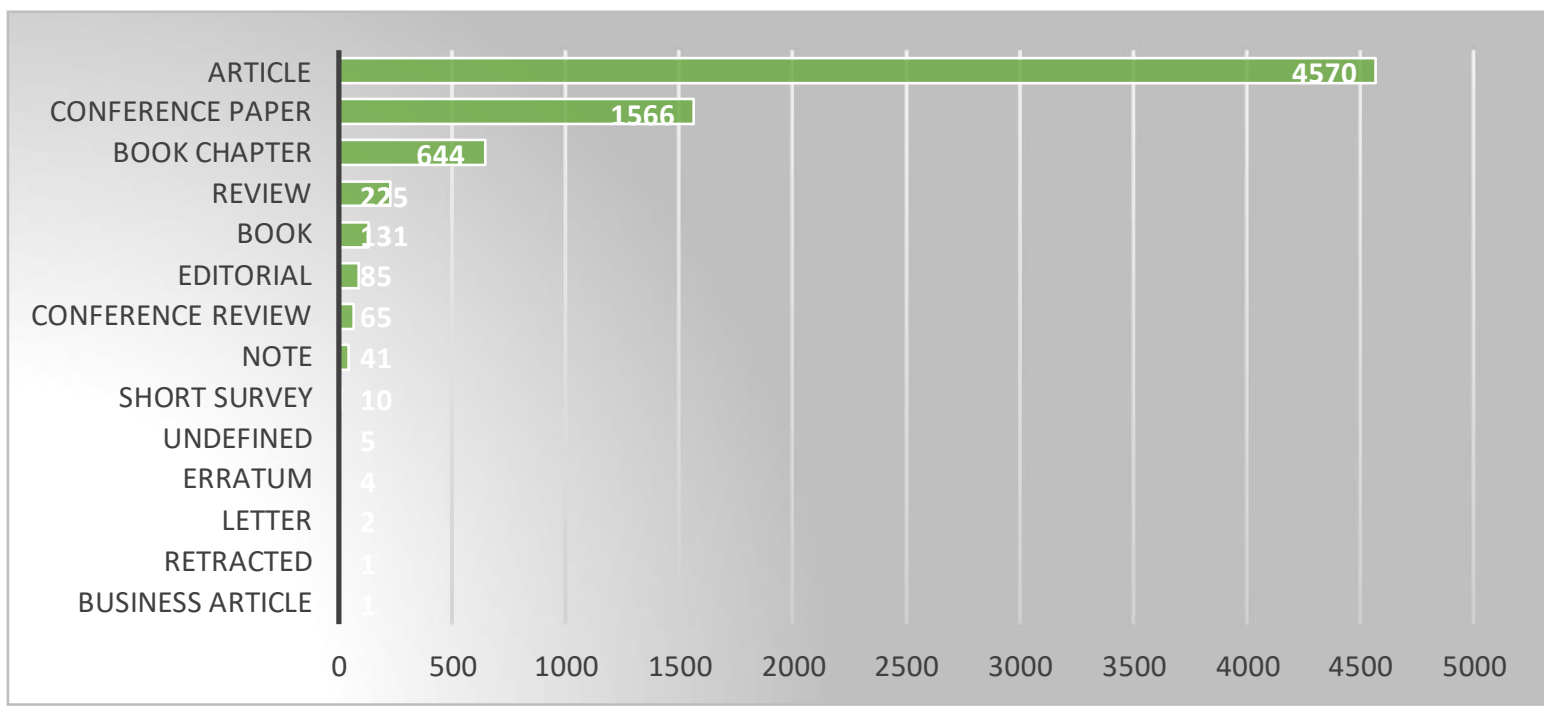

Source: Own elaboration 2021; from data supplied by SCOPUS

It is important for the purposes of the analysis of this study, to know what type of publication predominates in the total production of research works under the Big data variable in the organization since not only these publications correspond to a journal article, therefore it is detailed in Figure 3 the different categories through which it is published in high impact journals.

It is evident that most research works correspond to articles in scientific journals where a total of 4,570 units were published, distributed in the different countries mentioned in the previous point. Followed by conference papers and book chapters with 1,566 and 644 respectively.

An important participation of books and magazines whose central theme is the study of Big data oriented to the organization stands out, within which it is worth highlighting the book "Process mining: Data science in action" (van der Aalst, 2016) with a total of 829 citations, shows the reader effective tools in process mining to complement the study of data in areas of the organization such as production, commercial, among others. It offers the possibility of knowing the state of the art in process mining, which significantly helps in the study of different collection techniques and subsequent analysis of large amounts of information.

\section{Conclusion}

Decision making in any company will always be motivated by the need identified in the market and this is known thanks to several tools used by management, for example, a market study. When this market turns out to be of large proportions, the necessary tools for the capture, analysis and implementation of strategies have to be in accordance with Big Data techniques, due to the volume of information and the inability of conventional software to support large amounts of data. The accounting area does not escape the use of such techniques, since from the purchasing process to sales pricing, there are multiple variables that cannot be left to chance or to the speculation of the board of directors. The interpretation of the data collected in each investigation and its subsequent analysis produces the information as the main input for the creation of strategies and decision making in a company.

Accounting information systems are not only fed with historical information from different economic exercises carried out by the company, but also with information of essential importance for the economic sustainability of the organization, and as mentioned above, more and more companies are facing the challenge of covering large areas, not only geographically but also psychosocially in consumer behavior, and in the same proportion will be the volume of information to be processed. From this arises the need to apply Big Data techniques to the study of data from different areas of interest.

\section{References}

1. Aguilar, L. J. (2013). BIG DATA, Analisis de grandes volumenes de datos en organizaciones. Ciudad de Mexico: Alfaomega. 
2. Barrios, E. (2017). La contabilidad y los sistemas de información contable en las organizaciones.Buenos Aires: Rio Gallegos.

3. Fosso Wamba, S., Gunasekaran, A., Akter, S., Dubey, R., \& Childe, S. J. (2017). Big data analytics and firm performance: Effects of dynamic capabilities. Journal of Business Research, 356-365.

4. van der Aalst, W. M. (2016). Process mining: Data science in action .Eindhoven: Springer. 